\title{
Biological theory of depression in the light of new evidence
}

\author{
George Papageorgiou \\ From $1^{\text {st }}$ International Congress on Neurobiology and Clinical Psychopharmacology and European \\ Psychiatric Association Conference on Treatment Guidance \\ Thessaloniki, Greece. 19-22 November 2009
}

The finding of various structural and chemical abnormalities in the brain through neuroimaging has been the mainstay in depression research the last few years. Research isn't necessarily focused in a specific area of the brain, bur rather combines the pathophysiology of neurochemical communication of various brain areas to specific symptoms. The functionality of various brain areas, such as the prefrontal cortex or the amygdale or nucleus accumbens is theoretically linked with diverse symptom constellations. This might lead to more sophisticated treatment methods. New data on the function of the HPA axis and the role of CRF in stress response, contribute to the further understanding to the neurobiology of depression. As for the present therapeutic implications, the monoaminergic theory of depression is paralleled with the chronobiolgy theory and mainly with the theory of circadian rhythm dysregulation. All of the above lead to the rationale of the correct choice of antidepressants.

Published: 22 April 2010

\section{References}

1. Drevets WC: Neuroimaging studies of mood disorders. Biol Psychiatry 2000, 48:813-829.

2. Nestler EJ, Barrot M, DiLeone RJ, Eisch AJ, Gold SJ, Monteggia LM: Neurobiology of depression. Neuron 2002, 34:13-25.

3. Stahl SM: Stahl's Essential Psychopharmacology. Neuroscientific Basis and Practical Applications Cambridge Univ. Press, New York, NY, 32008.

doi:10.1186/1744-859X-9-S1-S47

Cite this article as: Papageorgiou: Biological theory of depression in the light of new evidence. Annals of General Psychiatry 2010 9(Suppl 1):S47.

Submit your next manuscript to BioMed Central and take full advantage of:

- Convenient online submission

- Thorough peer review

- No space constraints or color figure charges

- Immediate publication on acceptance

- Inclusion in PubMed, CAS, Scopus and Google Scholar

- Research which is freely available for redistribution 